\title{
A Methodological Overview of Oral History*
}

\author{
Michael D. Gibson
}

THERE IS little doubt that oral history has come of age. At last count there were some 500 projects in operation and probably the same number contemplated, finished, or in the process of formation.

Oral history is not new. The practice of interviewing individuals, and recording their impressions of the world, has been employed for centuries. Herodotus used this method in the fifth century B.C. in writing his history of the Persian Wars. As early as the 1840s in America, a librarian of some note-Lyman C. Draper-collected accounts of old Revolutionary War soldiers, a task he characterized as a "pious and thankless labor of rescuing from forgetfulness and neglect the memories of an interesting band of worthies." ${ }^{1}$ Draper's biographer claimed that he "was an expert interviewer, searching in his questioning and apt at drawing out information from old men who lived among their memories. He was critical too, and informed on all aspects of his special subject. Incessant and untiring in his search for truth, he led his informants into giving him all sides of their

${ }^{\star}$ Much of this article is based on a lecture delivered by Mr. Gibson at the Fall meeting of the Iowa Local Historical \& Museum Association (ILHMA) in Des Moines, October 22, 1977.

${ }^{1}$ William B. Hesseltine, Pioneer's Mission: The Story of Lyman C. Draper (Madison: The State Historical Society of Wisconsin, 1954), 28. 
stories in the first oral history project in America." ${ }^{2}$ Thankless as this job may have been, Draper left 486 bound volumes of transcripts with the State Historical Society of Wisconsin at the time of his death in 1891 . This collection, by the way, was heavily used by Frederick Jackson Turner in developing his theory of the American frontier. In California in the 1870s Hubert Howe Bancroft and his assistants took verbatim dictations of western pioneers - the results of which now form the nucleus of the Bancroft Library in Berkeley.

In the 1930s under the auspices of the New Deal and the Works Progress Administration, reminiscences of former slaves were gathered through manually recorded interviews. Of course all of these projects preceded coining of the term "oral history." The term itself seems to have originated in 1942 when a dissolute member of Greenwich Village and Harvard graduate, Joe Gould, claimed to be compiling "an Oral History of Our Time," according to a New Yorker profile. Suggested alternatives like "oral documentation" or "living history" have not survived. Some would say these are more accurate, and that "oral history" is a misnomer, although firmly embedded in our language.

But it was not until 1948 that oral history as we know it today was born. Professor Allan Nevins of Columbia University had become concerned that nothing was being done to preserve the legacy of people in the recent American past. Although he had first voiced this concern in the 1930s, it was not until a decade later that he could manage to take action to preserve such legacy. Frederick Bancroft, a fellow historian and one of Columbia's first Ph.D.s, left the university over a million dollars for acquisition of new materials in American history. A small portion of this $(\$ 3,000)$ was used by Nevins to start the first oral history program. The year was 1948 . The next year the wire recorder was used to interview Judge Learned Hand, and oral history as we know it today was born. By the 1950s the wire recorder had given way to more modern tape recorders,

${ }^{2}$ William B. Hesseltine, "Lyman Draper and the South," Journal of Southern History, 19 (Feb. 1953), 23. 
and Nevins was being called the "Father of Oral History."

What is oral history? Broadly speaking, oral history is the recording-generally by means of a planned interview - of the reminiscences of persons who have participated in or observed events of historical interest. These reminiscences are taken down fully by some stenographic method-today that method is usually the tape-recorder. Through pre-planned interviews, the information is captured in question-and-answer form. What makes oral history unique is that it records a planned, structured, interview that will be useful to a wide range of researchers in the future. The questioning is often wider in scope and broader in range than journalism or specific historical research interviews. These personal, first-hand recollections clarify and supplement information contained in manuscript and published sources. And, like manuscripts and published sources, they must be made available to researchers. Allan Nevins was concerned about its accessibility when he first initiated the program at Columbia University. He stressed not only the technique for recording information, but also the service to be provided to future generations of researchers. Strictly speaking, then, the term "oral history" should be limited to cases in which a taped interview is transcribed and made available to other researchers. Of course, also in a strict sense, the product emerging is neither oral nor history because the tape recorded interview is considered an intermediate step toward a typewritten manuscript, and this transcript is not history, but raw material from which historians can work.

However, this does not mean that the actual recorded interview has no intrinsic value. Quite the contrary, one of the major values of oral history is the fact that the physical voice is preserved on a tape and conveys many intangibles the written words cannot. The voice can betray one's age, one's class, one's sensibility, one's education. The meaning of a word or phrase can be modified by the inflection in a voice. The value of oral history to the researcher is not so much in the detailed new knowledge he will obtain but in having certain intangibles of a past era revealed. This was best described by a scholar who ironically was questioning the worth of oral history: 


\section{The Annals of Iowa}

Interviews are particularly useful in getting at 'emphasis' and 'atmosphere.' Emphasis, roughly defined, means an indication of the relative importance assigned to the issues by the participants themselves; and atmosphere may be defined as the social, political, economic, and personality interrelationships that explain why certain issues were important and others were not. Moreover, interviews can provide an understanding of unexercised alternatives and may open the door to the subjective 'feel' of a person or a period ... emphasis on certain words, the suppressed chuckle when a seemingly humorless phrase comes up, are intangibles not found in documents. The excitement, frustration, boredom, or humor of a particular situation are often not discernible in the written records. Oral history techniques offer the possibility, without guaranteeing success, of recapturing the mood and the spirit of men and their times. ${ }^{3}$

This is why it is necessary to retain tapes even after a transcript has been made. It seems to me the real value of oral history lies precisely here, in the "feel" it conveys for people and for their time. Hopefully those who practice oral history techniques will gain great satisfaction from preserving information and "feelings" that might otherwise be lost forever.

IT IS IMPOSSIBLE here to provide a manual of oral history technique. There have been numerous such manuals written in the last few years, and they are readily available to the public in libraries and historical societies. Most of these manuals are listed in the bibliography accompanying this article, and the reader is encouraged to consult them for detailed "do's" and "don'ts."

There are a variety of types of oral history projects. At first oral history was primarily applied to visible people in our history: presidents, armed service leaders, civil rights leaders, union leaders, etc. Presidential Libraries such as the Herbert Hoover Library in West Branch, Iowa contain such oral history materials. Subsequently other types emerged: (a) Special sub-

${ }^{3}$ Donald Swain, "Problems for Practitioners of Oral History." American Archivist, 28 (Jan. 1965), 68. 
ject. Tulane University Oral History specializes in jazz musicians, and several universities, including the Iowa Labor Oral History Project currently being sponsored by the University of Iowa, collect tapes on labor history. (b) Ethnic and cultural history. The Church of Jesus Christ of Latter-day Saints in Salt Lake City is sponsoring a project to preserve oral genealogies of people in the South Pacific, and South Dakota has a project dealing with the American Indian. (c) Institutional history. History of a university, a church, a business, etc. (d) Regional projects. Family history, history of a community, history of a club, history of a local historical society. This combines the "great men" with the "common man" and may even touch upon ethnic, cultural, and institutional history.

Both as individual and as group enterprises, oral history projects can take place in many contexts-in schools, in universities, in community centers, in local historical societies. Groups formed to conduct oral history projects may want to form committees charged with making surveys to determine what developments were important in the creation of particular communities. Determination of what information (in the form of manuscripts, published sources, photographs, etc.) already exists is recommended. And finally, identification of reliable informants can mean all the difference in the world to a successful project.

Choosing a topic is one of the first steps, and is vitally important. The subject should be sufficiently defined, localized, and relevant to wider historical issues. This is especially important when delving into the realm of trends, influences, or larger concerns. Each interview should fit into a larger picture, unless one is interviewing solely for family history and genealogical purposes.

"Folklife in Rural Iowa" is an example of an oral history project that proved highly successful, partly because the topic was so clearly defined. The project was accomplished during six weeks in the summer of 1978. Two teams of fifteen people conducted over eighty interviews with residents in northwest Iowa. The project was under the auspices of Earthwatch, a non-profit organization headquartered in Massachusetts. The State Histor- 


\section{The Annals of Iowa}

ical Society of Iowa served as co-sponsor and provided technical assistance. According to Rebecca Conard, the Field Director, "the primary objective was to gather first-hand data on land stewardship in rural lowa during the early twentieth century, that is, information about how rural land has been farmed and passed on from generation to generation. . . ."4 The tapes and transcripts are now housed in the oral history collection of the State Historical Society for use by students and researchers.

After a central topic is decided upon, selection of informants is crucial. The "Folklife in Rural Iowa" project defined a geographical range and then identified prospective informants. Northwest Iowa was the target, and Century Farm books listing owners of farms that had been in the family for at least 100 years were used to find informants. From the 400 people that were selected and sent letters and questionnaires, over 100 responded. These people were contacted and interviews scheduled.

Finding the best and most diverse group of informants for the interviews should be a priority in planning any oral history project. There is no point in recording people whose memories are confused or impaired, or who are too withdrawn to talk about them. And the most prominent people in a community are not always the best informants-remember, what matters is the "direct" personal experience that somebody has, rather than his or her status. Personal contacts and referrals have proven most satisfactory in reaching reliable informants, and sometimes media advertisements help bring items to the project director's attention. Preliminary screening is invaluable in weeding out inadequate informants.

Once the topic is defined and the informants selected, the technical aspects of oral history can be addressed. A biographical sheet for the informants is useful. Some biographical information will be revealed in the interview, but a questionnaire sent out prior to the interview and returned ensures systematic recording of pertinent data (See Sample 1: Data Sheet). To pre-

'Rebecca Conrad, "Summary Field Report for Folklife in Rural Iowa," (July 1-August 12, 1978), 1. 


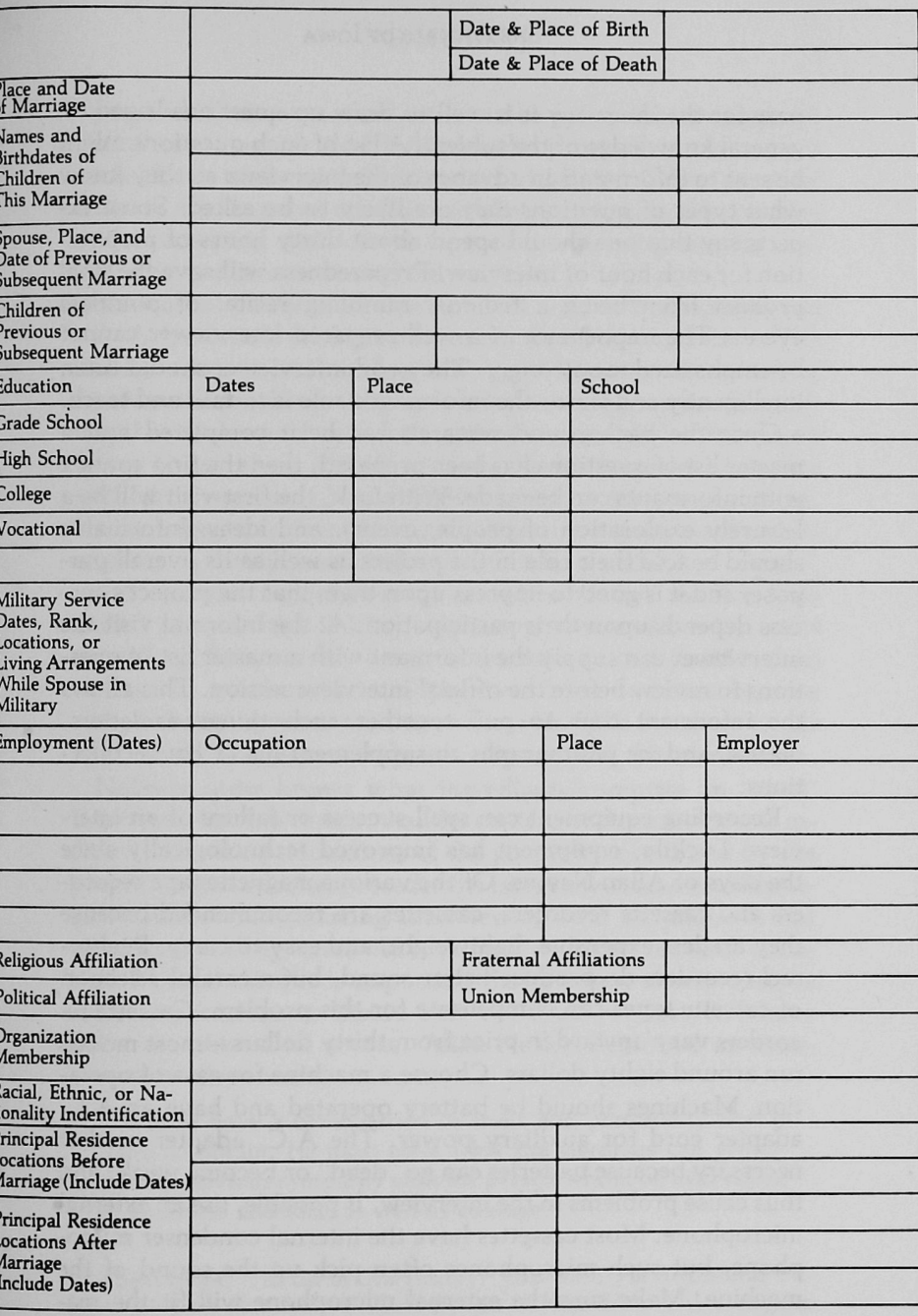

Reproduced from Your Family History: A Handbook for Research and Writing, by David E Kyvig and Myron A. Marty, (courtesy A. H. M. Publishing Corporation). 
pare for the interview it is well to draw up questions based on general knowledge of the subject. A list of such questions might be sent to informants in advance of the interviews so they know what types of questions they are likely to be asked. Some experts say that one should spend about thirty hours of preparation for each hour of interview! Preparedness will save the final product from being a tedious, rambling recital of pointless events. The importance of a well-prepared interviewer cannot be emphasized too strongly. The good interviewer should listen intelligently and learn; the informant's role is to talk and teach.

Once the background research has been completed and a master list of questions has been prepared, then the first contact with informants can be made. With luck, the first visit will be a leisurely exploration of people, events, and ideas. Informants should be told their role in the project as well as its overall purpose; and it is good to impress upon them that the project's success depends upon their participation. At the informal visit the interviewer can supply the informant with a master list of questions to review before the official interview session. This allows the informant time to pull together such things as letters, diaries, and/or photographs to supplement his or her recollections.

Recording equipment can spell success or failure of an interview. Luckily, equipment has improved technologically since the days of Allan Nevins. Of the various magnetic tape recorders and cassette recorders, cassettes are recommended because they are less expensive, lightweight, and easy to carry. Reel-toreel recorders do produce better sound, but a careful selection of cassette tapes can compensate for this problem. Cassette recorders vary upward in price from thirty dollars - most models run around eighty dollars. Choose a machine for ease of operation. Machines should be battery operated and have an A.C. adapter cord for auxiliary power. The A.C. adapter cord is necessary because batteries can go "dead" or become weak, and thus cause problems in the interview. If possible, use an external microphone. Most cassettes have the internal condenser microphone, but such microphones often pick up the sound of the machine. Make sure the external microphone will fit the ma- 


\section{Oral History}

chine and has its own stand, so it can be propped at an angle. A digital tape counter that indicates the progress of the tape is useful both while recording and in playback. Other practical features are the pause control, enabling you to stop the machine without creating slack on the tape, and a carrying case for convenience and protection of the machine.

Two other pieces of equipment that are not essential but are very helpful are a demagnetizer and a dictaphone machine. The demagnetizer neutralizes magnetic particles from the recording head on the machine. (Magnetic tape contains iron oxide particles that coalesce when voice imprints are recorded. After many hours of use, these rub off on the magnetic head and interfere with clear recording.) After every twenty hours of recording, the demagnetizer should be used. If you are going to do transcribing, a dictaphone machine with a foot pedal is a "must."

For interviewing purposes it is best to always use the "low noise" tapes-"high fidelity" tapes are too sensitive for voice recording. Sixty-minute cassettes are recommended rather than ninety- or one-hundred-and-twenty-minute cassettes because sixty-minute tapes are thicker and less likely to break or tangle up, and divide conveniently into segments of thirty minutes.

Nobody quite knows what ingredients comprise an "ideal" interview, but it is certain that the content of the interview is influenced by the personalities of the people involved and by the preparatory work that precedes the interview. Some oral historians caution that reducing interviewing to a technique is not satisfactory. They stress old fashioned intuition for each situation. Nevertheless, it is important that the interviewer observe some conventions to insure that the final product will have value as a historical source. Allan Nevins described an interviewer in these terms:

He must have a combination of traits and personality that is hard to obtain. He must have what the Germans call gemutlicheit, obvious sympathy with the person whom he interviews, friendliness and tact, as well as courage. ${ }^{5}$

${ }^{5}$ Allen Nevins, "The Use of Oral History," Oral History at Arrowhead: Proceedings of the First National Colloquiuum on Oral History (Los Angeles: Oral History Association, 1967), 40. 
It goes without saying that the interviewer should be alert and mentally prepared or "psyched up" before each interview. Besides generating enthusiasm, he or she should try to create a relaxed atmosphere throughout the interview. A good way to begin is by demonstrating the cassette recorder and allowing the informant to hear his/her voice on tape. This will also permit proper adjustment of the volume and placement of the microphone. Blank tape- "lead-in" tape-should be left for a later recording of a formal introduction stating the name of the informant, the interviewer's name, the date, and place of the interview. Nothing will give an informant "mike fright" more surely than if the interviewer first records a formal introduction, then turns and says, "You are on the air."

Be sure the recorder is in plain sight so it can be observed, as inconspicuously as possible, during the interview. The presence of a third party during the interview should be discouraged unless a husband and wife or brother and sister are being taped together. Taking notes during the interview is helpful to get down correct spellings, places, dates, or other items which might need elaboration. Keep in mind that although the interviewer's job is to exercise careful control, he or she should never dominate the interview. The narrator should be allowed freedom to do most of the talking and to set the pace, and certainly the interviewer should never put the informant into a defensive position, consistently challenging, correcting, or contradicting what is being stated. The questions should be "open-ended" (not loaded with a certain response such as "yes" or "no"). Start with the "why, how, where, what kind, when, etc." questions. Give the interview spontaneity, but don't allow the conversation to run onto several tangents at once. If the narrator strays too far afield (often this happens when spinning "tall tales" or telling about a family ailment) try to pull him back as quickly and diplomatically as possible to your original questioning.

There are certain techniques that can be employed to maintain direction in an interview. Always try to establish at every point where the informant was and what his role was in an event. This will help to keep a focus on how much of what is being related is eye-witness account and how much is heresay. 
When it is difficult for the narrator to describe certain people, ask him first to describe the physical appearance-from there it is easier to move to a character description. The interviewer might phrase questions in a negative tone and ask about negative aspects of a situation because people tend to remember these better. For example, in asking about an individual do not describe him in glowing terms because in most cases the informant will hesitate to disagree. Don't say, "I understand Mr. Smith was a very wise and generous person. Did you find him to be so?" Rather, say, "Despite Mr. Smith's reputation, I understand he was difficult to get along with. Is this so?" The informant will either step to the defense of the person with a description of why the interviewer is wrong, or why he is correct. On the other hand, try to avoid "off the record" information or "character assassination." If the informant asks to have the recorder turned off so he can say something "off the record" advise him that it would be better to record what he has to say and place a restriction on that portion of the tape.

THE AVERAGE length of an interview is between one and one-and-a-half hours. Generally, better results are achieved when the interview is conducted in a leisurely fashion over a number of days rather than concentrated in one long day. A "release form" with the signature of the informant should be obtained. The form should contain any restrictions which the narrator may wish to place on use of the tapes. If only portions of the tapes are restricted it should be so noted. (See Sample 2: Release Form.) The new copyright law (January 1978) states that copyright remains with the narrator unless he or she signs it over to the interviewer or an agency. This means that if any item of the tape is used in published form the narrator or his heirs must give permission. This is why copyright can be signed over on the release form if desirable.

It is also wise to get a photograph of the narrator for the files before leaving. Record any comments of your own on the context of the interview, the character of the informant, etc.. Record the introduction on the lead-in tape and mark both the tape and its box with the appropriate identifying data. 


\section{The Annals of Iowa}

\section{ORAL HISTORY AGREEMENT}

I the undersigned, do hereby consent to a tape recorded interview and further consent to the transcribing of said interview by the Division of the State Historical Society, or its agents. It is understood that said interview is to be kept and maintained by the Division of the State Historical Society as part of its Oral History Collection for use by students and scholars for as long as the agency believes said materials to be of scholarly or historical value.

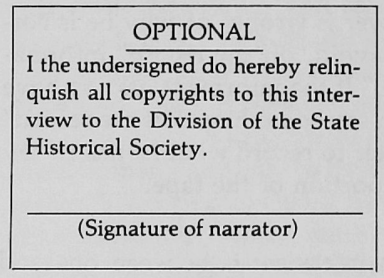

(Name of interviewer)

(Date of interview)

(Location of interview)

(Number of tapes)

\section{(Signature of narrator)}

(Address)

(Date)

\begin{tabular}{c}
\hline (Address) \\
\hline (Date)
\end{tabular}

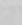


Once the interviewing is completed and the data is collected, a decision should be made concerning whether or not the material will be transcribed and edited, and how it will be preserved for future use. The first transcription should be made by the interviewer since he is more familiar with any idiosyncrasies which might exist and is better able to make corrections using his notes. The interviewer's primary responsibility in transcribing is to clarify thoughts with the least possible alteration of the text.

Transcribing is the most costly factor in oral history both in terms of time and money. A dictaphone machine, or a foot pedal for the recorder is necessary, although it means an initial expense. A typist's services can also be expensive. In general, between six and eight hours will be spent in transcribing for every hour of interview. But tapes that are not transcribed will probably not be widely used by researchers. It is a question of usability vs. costs.

It is best if the interviewer is able to transcribe the rough draft. A typist who has as broad a general background as possible would be the second choice. Next to the interview itself, the process of transcribing requires the greatest skill. It is a work of art, akin to translating from one language to another because the spoken word has so many nuances (pitch, loudness, strength, weakness, speed, pronunciaton, etc.) which convey facts and feelings. The transcriber has to be accurate not only in putting down the facts, but also in trying to retain the flavor and feeling of the narrator. The more the transcriber knows about the topic, the more accurate will be the transcript. The interviewer must always check the first draft of the transcript against the tape. A copy of the final transcript should be presented to the narrator as a "momento of the project."

How much editing is done will depend upon what is desired in the final product. Some projects seek to preserve exact information about past events; others seek attitudes and feelings; and still others, speech patterns, modes of expression, and folk phrases. The latter requires verbatim transcription. The others require some editing-enough to produce historical accuracy but not so much that the flavor of the interview is destroyed. 
Editing should concentrate on verifying words which are hard to hear, adding written comments to clarify points, correcting spellings, checking names, places, dates, etc.. It should not include correcting errors in grammar, eliminating questions or responses, improving phrasing or rearranging thought sequences. Several books listed in the bibliography discuss the details of editing oral history transcripts. The purpose of editing is to produce a manuscript that is the closest possible rendition of the spoken interview and at the same time historically authentic and acceptable to the narrator.

If a transcript is not made, an abstract highlighting the interview topics using the digital counter on the recorder is warranted. If this is not possible, a table of contents for the interview or an outline is advisable. A goal to keep in mind is that the material must be readily available to future scholars.

Conservatory practices will insure preservation of the actual tapes. The tapes should be stored in areas having some constant temperature $\left(70^{\circ}\right)$ and relatively low humidity $\left(50^{\circ}\right)$. They must be kept away from electrical motors which can reverse the magnetic polarity and ruin them. The tapes should be rewound occasionally (once a year if possible) because they tend to "bleed" or "print through" and this will eventually distort the sound. Keep the recording equipment free from dust, and clean the magnetic "head" of the recorder periodically.

For accessibility to others, tapes should be deposited with a historical society or library which has an oral history collection. Since oral history tapes supplement other historical items (diaries, photographs, letters, etc.) they belong in historical collections. Transcript, photographs, copies of diaries, letters, etc. should be deposited with the tape. Most depositories are equipped to make archival copies of the tapes so the originals are not used. Those with full-scale oral history programs are also able to provide indexes and catalog cards for the tapes. Once the interviewer has deposited the tape and transcript with a depository, he will have the satisfaction that he has contributed to the history of man in a small, but important, manner. 
LIKE THE photograph, the tape recorder has made a significant impact on our notions of history. Bringing us the human voice, it has expanded the scope of history into the social and personal realm. History is based not only on laws, statistics, documents, and the lives of leaders, but also on man's common experience. Some critics claim oral history is inaccurate. Human memory is often faulty, too short, at times confused, and at times simply wrong. But is this true only of oral history? Is not the memory of a diarist at times as faulty? Like all historical "documents," oral history must test every piece of evidence, before claiming for itself the value of testimony. Precisely here oral history has an advantage. The interviewer, because he is talking to a real person who actually witnessed the events described, can try to clarify ambiguities. He can prod the informant's memory and if necessary even cross-examine his "source." True, oral history can capture the past only as it is seen through the eyes of the present. Yet it can produce a feeling for the past in a way other source materials do not. I have stressed the "feel for an era" one can obtain by interviewing. People no longer have to passively learn about their past; they can write it. As one oral historian so aptly put it, "Oral history gives history back to the people in their own words. And in giving a past, it also helps them towards a future of their own making."

Consider what Edmund Spenser wrote in The Ruines of Time in 1591 A.D.:

For deeds do die, how ever nobile donne,

And thoughts of men do as themselves decay,

But wise wordes taught in numbers for to runne,

Recorded by the Muses, live for ay.?

The Muses, oral historians, must preserve that firsthand knowledge from decay, "for ay" -and for the benefit of future scholars. Perhaps oral history can teach us not only to trust those over thirty, but to listen to them.

'Paul Thompson, The Voice of the Past: Oral History (London: Oxford University Press, 1978), 226.

"Edmund Spenser, "The Ruines of Time" from The Works of Edmund Spenser, IV, ed. by J. Payne Collier, (London: Bell and Daldy, 1862), 311. 
Copyright of Annals of Iowa is the property of State of Iowa, by \& through the State Historical Society of Iowa and its content may not be copied or emailed to multiple sites or posted to a listserv without the copyright holder's express written permission. However, users may print, download, or email articles for individual use. 